\title{
Newroz from Kurdish and Persian Perspectives - A Comparative Study
}

\author{
Hewa Salam Khalid 1 \\ Kurdish Language Department, Koya University, Kurdistan Region - Iraq
}

\begin{abstract}
The celebration of Newroz/Nowruz at the beginning of spring has a long history among Aryan ethnic groups such as Kurds, Persians, Afghans, Azaris, Tajiks, and Balochs. Newroz, as one of the most important festivals of the ancient Iranians, is a symbol of rebirth, freshness, freedom, and peace. Although its exact date of observance may vary from an ethnic group to another, it mainly occurs between 19th to 21st of March because of its linkage with the Spring Equinox. The festival has been listed among the Intangible Cultural Heritage of Humanity by UNESCO. This study analyzes Newroz according to Kurdish and Persian perspectives. The primary purpose is to investigate diverse cultural perceptions toward the ancient festival among these two nations, and the way they celebrate it. The qualitative research method is used, and semi-structured interviews have been conducted to explore significant differences and similarities between the two nations' celebrations of Newroz. The participants of the study were selected using the judgmental sampling technique. Results indicate that there are numerous differences in celebrating Newroz. For the Kurds who are a stateless nation, besides its cultural background, Newroz is a symbol of resistance while for Persians it is a pure cultural festival. Even though it marks the beginning of the Kurdish and the Persian new year, their calendars, myths, the way they celebrate it, and their understanding for its origin are different.
\end{abstract}

Keywords: Newroz/Nowruz, Kurds, Persians, intangible cultural heritage, origin of the Kurds.

\section{Introduction}

Newroz (Kurdish: نهوروز / نوروز Newroz, pronounced [nعw'ro:z]; Persian, pronounced [now'ru:z]) is one of the oldest Aryan festivals and has been celebrated by different ethnic groups and faith communities in the Middle East and some other parts of central Asia (UNESCO, 2010). It is an annual festival and the beginning of the new year among various national groups, mainly Kurds and Persians. The festival is recognized as the Intangible Cultural Heritage of Humanity by UNESCO and seen as the celebration of Kurdish national identity by the Kurds. There are different perspectives about the origin of the festival, its mythology, the way to celebrate it, and its cultural and political influence. However, both nations are still under the influence of Zoroastrianism which is their original religion.

Kurds, as a stateless nation, believe that Newroz dates back to the emergence of the Median Empire around 700 BC. According to the Kurdish myth, Kawe- and their ancestor killed Zuhak - زوحاك/ Zahāk, the tyrant. To spread the word about his success,

1 Lecturer, Kurdish Language Department, Koya University, Kurdistan Region - Iraq.

E-mail: hewa.salam@koyauniversity.org 
he lit a bonfire on a mountain, and it was a new day for Kurds and all the other Aryan ethnic groups. After that, Deioces - دياكوّ Deiokes was chosen by seven Kurdish tribes to build the Median Empire, and Deioces succeeded in building the empire. The event is annually celebrated in the time of the spring equinox, and the exact day of Kurdish Newroz is the 21 st of March. Newroz is a political and cultural festival, and Kurdish Newroz celebrations are different from those of other nations. However, even the Kurdish communities living in different countries across the Middle East do not celebrate Newroz in the same way and that might be because they do not have a shared state identity.

Persians believe that Nowruz is the day of the Spring equinox that usually occurs on the 19 th, 20th or $21_{\text {st }}$ of March. According to the Persians, Nowruz has no links with the story of Kawe and Zuhak. However, like the Kurds, they narrate the epic story of Kawe and Zuhak since it is a part of their folktales and it was first written down in Shahnama by the renowned Persian poet Ferdowsi. Ferdowsi wrote his famous Shahnama in the tenth century. He has linked Nowruz with Jamshid the legendary ruler of the ancient Iranians. According to the Persian myth, Jamshid fought against winter, went above the earth into the heavens, and he was shining like the sun. The event was the beginning of a new day known as Nowruz. Nowadays, Persian celebrations during Nowruz are cultural and have no link with their political aspirations. Annually, they start to celebrate in the last Wednesday before Newroz that is called Chaharshanbe Suri / Festive Wednesday', and they go out for a picnic after thirteen days of Newroz. It is called Sizdehbeder / 'Thirteen Outdoor', and they decorate a special table which is called the Haft-sin.

This study seeks to understand the similarities and differences between Kurdish and Persian Newroz/Nowruz from their perspective and to explore whether being abroad has caused any changes in the festival. To do that, many sources and documents have been analyzed and new understandings are discussed. In the literature review, Kurdish and Persian origin and rituals for Newroz are analyzed. The study is also supported by the empirical foundation. Finally, the findings have discussed that lead to the conclusion.

\section{Literature Review}

Newroz means 'New Day' in both Kurdish and Persian, and consists of two morphemes; 'New' means new and 'Roz' means day. Historically, Newroz was called 'Nokroj which has the same meaning as Newroz, and according to Anwar (2016, p. 15), its etymology dates back to Pahlavi, which was one of the old Iranian languages. 'Nok/نوّك' means 'new' and 'Rojوجر' means day. The latter is still used in the Zazaki dialect of Kurdish language. The International Day of Newroz is usually on the 21 st of March. It is the time of the Vernal Equinox in which many people all over the world celebrate it as the start of the New Year. Newroz festival has been observed in different parts of the world such as Balkans, the Middle East, Central Asia, the Black Sea Basin, the Caucasus, and other regions over 3000 years (UNESCO, 2010).

The origin of Newroz is unclear. On the one hand, the Kurds link Kawe and Zuhak mythology to Newroz. The Persian Shahnama that was written in the tenth century by Firdawsi is the oldest available writing that narrated the myth. In short; many years ago, there was a world ruler, Jamshid. Zuhak marched against Jamshid, hunted Jamshid for many years, and at last killed him. Zuhak had become the new ruler and the new tyrant. He killed two young people daily to feed the two snakes on his shoulder. Many years later, Kawe killed Zuhak and became a legend. Firdawsi (Firdawsi, 2006) said the Kurds had run to the mountains because of Zuhak brutality. Also, the

Kurds believe that Kawe, who killed Zuhak and then lit a large bonfire to tell the people of Mesopotamia that they were free, is their ancestor (Hirschler, 2001). The Kurdish claim is 
understandable and meaningful, however, Firdawsi has not mentioned Kawe's ethnic identity. Interestingly, the word 'kurd/ куырд' means 'blacksmith' in the Ossetian 'Alan' language, which is one of the Iranian languages and a sister language of Kurdish and Persian 'Farsi' (Belyaev, 2010). So, their language and culture can be helpful in the Aryan origin contexts. My understanding is that the meaning of ' $k u r d /$ кyыpd' has been expanded from Kawe's profession to his ethnic name and identity. After his victory, the word of 'Kurd' would have been used for his followers and successors. This type of expansion is very popular among the Aryans and many other ethnic groups. Based on this context, we can say that the word Kurd comes from Kawe's profession 'kurd/ кyырд', which means 'blacksmith'.

Masudi and Istakhri, two tenth-century Arab writers, as well as Sharafkhani Badlisi the sixteenth-century famous Kurdish historian also mentioned the Kurdish mythology of Kawe and Zuhak (Özoglu, 2004). Kurds link this story to the emergence of the Median empire, and they believe that the Kawe's bonfire was the first Newroz bonfire that marked the beginning of a new day in Kurdish history. After the collapse of Zuhak's tyranny, the Median Empire was founded. Historically, the empire was created by the Medes around 700 BC (Anwar, 2016). The orientalist and Kurdish expert Vladimir Minorsky was the first researcher who claimed that the Medes are the ancestors of the Kurds (Özoglu, 2004). His understanding is widely accepted. Deioces was the first king of the Medes but his name and reign are the subjects of controversy. On the other side, the Persians link Persian Nowruz to Jamshid who was a mythical Iranian King, and it was narrated in Shahnameh (Firdawsi, 2006). However, they believe that Nowruz and the myth of Kaveh/o sand Zahak/ ضحّاك has no connection. Persian Nowruz festival represents the beginning of the spring and renewal of nature (Zamani-Farahani, 2013). According to UNESCO, Newroz is a festival that transcends national boundaries and promotes the 'values of peace and solidarity between generations and within families as well as reconciliation and neighborliness, hence contributing to cultural diversity and friendship between peoples and different societies' and for that reason, it is listed as an Intangible Cultural Heritage of Humanity (UNESCO, 2009). Interestingly, UNESCO has excluded the Kurdish spelling of the festival name, and its proclamation about Newroz does not mention the Kurds and other stateless nations that observe this festivity. This could be because of the influence of the nation-states on UNESCO, in particular Turkey and Iran. Regarding its origin, as discussed, the Kurdish Newroz linked with a historical event but that history remains unclear. However, according to the Persians, Nowruz is a mythical festival.

Nowadays, Newroz plays a vital role as a symbol of national identity and tourism resource for both nations. Generally, there are many reasons behind forming festivals within communities, including presenting cultural heritage, attracting tourists, promoting destinations, offering cultural entertainment to residents, aiming at improving the quality of life (Cudny et al., 2012). Most studies agree that tourists, in general, at least participate in one of the cultural events when they travel (Okech, 2011). Festivals believed to be significant cultural activities that can attract tourists to the destinations. According to Janiskee (1980), events and festivals are defined as 'formal periods or programs of pleasurable activities, entertainment, or events having a festive character and publicly celebrating some concept, happening or fact.' In the tourism sector, events, festivals, and ceremonies have been recognized as crucial attractions for tourists, and thus, they greatly contribute to destination development plans. Such activities are essential for the community in different aspects such as cultural development, urban planning, strengthening national identity, enhancing local community image as well as tourism development and planning. Throughout history, people from different cultures have used ceremonies and festivals as a means to show their joy, happiness, success, and achievements. Depending on the culture, a variety of names assigned to these events, such as; festivals, carnivals, fairs, festivities, feasts, and carousals that are part of local, regional, 
national, and international activities. Festivals enable people to share their culture, experiences, and knowledge. Moreover, it can present local customs and traditions to tourists and show the way a nation celebrates its holidays (Luna, 2015). Most of the national events and festivals rely on already existing infrastructures and provide visitors with an opportunity to take part in interesting activities. Locals generally lead the events, and there exists a high potential for small businesses to make a profit (Getz, 1993). Cultural festivals that are usually sustainable play essential roles, such as supporting indigenous and locals to preserve their lifestyle and feel proud of their culture and identity. Also, it is an economic activity that brings benefits to local communities, leads to sustainability, and encourages an equal share of profits among all stakeholders. Cultural festivals are very advantageous to show performances, which can lead to an increase in the value of the community (Okech, 2011). So, a deeper understanding of Newroz and its values can have positive implications on the stakeholders, authorities, and ethnic groups. In recent decades, festivals and ceremonies have developed the leisure industry and become cultural attractions in countries with popular tourist destinations (Crompton \& McKay, 1997; Getz, 1993; Thrane, 2002; Woofter, 2019). To look at Newroz as a tourist attraction, we need to understand the celebration, indigenous peoples' perspective, background, and rituals. Thus, we are going to analyze the Kurdish and Persian Newroz/Nowruz rituals differently:

\section{Kurdish Newroz Rituals}

Newroz is considered as the Kurdish New Year, and the current year in the Kurdish calendar is 2720. Although, 21 st of March is designated as a new day and called Newroz. The Kurdish calendar renews according to the Spring Equinox, and the first day of spring is 1 st of Khakalewa 'خاكهليّوه' (Izady, 1992), which might be on 19th, 20th or 21st. Kurdish Newroz has both cultural and political significance. It starts with lighting a bonfire and jumping over it on the evening of 20 th March. On that day, people gather together near the fire, wearing traditional Kurdish clothes and hope for a better life. The ritual of blessing fire has come from Zoroastrianism which is an ancient Aryan religion (Qeredaxî, 2017). More cultural dimensions of the event including the symbols, gifts, food, and other cultural rituals of Kurdish Newroz have been shown in the findings.

Kurds have not had their independent state in modern history and therefore their traditions have been under the influence of the dominant cultures of the main four countries that they reside in. Greater Kurdistan, where Kurds seek to establish their independent state on is a geo-cultural historical region that has been divided among the four nation-states; Turkey, Iran, Iraq, and Syria. For decades, the political atmosphere in each part of Greater Kurdistan has determined how the Kurds celebrate Newroz. That is why, in contrast to the other ethnic groups's celebrations of the festival, the Kurdish Newroz celebration has also a political dimension (Izady, 1992; Kolcak, 2015). After the collapse of the Ottoman Empire and creations of the nation-states in the region, Kurds could not achieve their dream of building their nation-state (McDowall, 2004). That could be the reason why now the Kurds see Newroz not only as a cultural festival but also as a political one. However, Kurdish Newroz is a political myth itself. Removing and killing a tyrant by the blacksmith is a political action. To explain the political dimension of Kurdish Newroz, we are going to clarify the political situation of each part of Kurdistan differently:

In Iraqi Kurdistan, where is the home of the modern Kurdish nationalism and has been the center of Kurdish nationalism for decades, Kurdish people and the Kurdish political groups have always tried to make Newroz a new beginning for the Kurdish question, and Newroz has become a tool for this demand. After the collapse of the Ottoman Empire, Piramerd, who was a famous Kurdish poet and politician, returned from Istanbul to Sulaymaniyah. He started to celebrate 
Newroz in an organized way and invited the locals for the celebrations by offering Kurdish food and drinks on the Mama-Yara hill (Hakim, 2016). After several years, this new style of celebrating Newroz became a norm, and nowadays it is synonymous with the Kurdish Newroz celebration style. The 1945 Newroz is one of the most well-known celebrations in Kurdish history. Cecil J. Edmonds, the adviser to the Ministry of Interior in Iraq who was the shadow governor visited Sulaymaniyah for the last time. During his stay in the city, he attended Newroz celebration where the Kurdish poet Bekas stood in front of him and read a revolutionary poem to the people who had gathered there to celebrate Newroz (Bekas, 2013). It was an unforgettable moment for participants because the British mandate in Iraq had played a pivotal role in linking this part of Kurdistan to Iraq and had buried the dream of the Kurdish liberation movements for Kurdish independence. The event has become a sign of Kurdish resistance against oppression. Thus, the norm has been supported by the Kurds, and it has become a national tradition. The prohibition of Newroz by the Iraqi governments from time to time has strengthened the political dimension of Newroz. During the Kurdish uprising in 1991, "Kurds declared the success of their insurgency in Iraq and repelled the Iraqi forces from the last disputed city, Kirkuk, on 19th March" (McDowall, 2004, p. 372), and they could light the Newroz bonfire there. After obtaining Kurdish autonomy in Iraqi Kurdistan, Newroz has been formally recognized as a national holiday to celebrate Kurdish identity, and the preceding three days are also a part of that national holiday (KRG, 2020). As it is clear, the Iraqi Kurdistan events have had a direct impact on the other parts of Kurdistan.

In the case of Kurdish people in Turkey, they have been denied their cultural and political rights for decades by the Turkish state. Their custom, language, and traditions had been banned by law for years, including Newroz. Turkish state tried to erase this celebration or melt it in the Persian version of Nowruz because Kurdish people do not celebrate Newroz only as a cultural celebration; they see it as a day for renewing their dream and resistance, which is a political vision (Hirschler, 2001; Jamison, 2016; Yanik, 2006). In the 1990s, the Kurdish municipalities in Turkish Kurdistan were forced to use the word Nevruz instead of Newroz because of letters such as Q, X, and W prohibited by law (Jamison, 2016). These letters are available in the Kurdish Latin alphabet, but they are not available in the Turkish alphabet. Modern Turkey has been built on 'one nation, one language, and one country' slogan which is still practiced by the Turkish state. So, Kurds and other ethnic languages and customs were banned for years. However, Kurds never accepted the prohibition, and they have celebrated Newroz in the most difficult situations. The price of such celebrations has been painful; The first formal permission for the Newroz celebration in Turkey was in 1992 which led to a massacre. Turkish armed forces killed hundreds of civilians in the town of Cizre which is known as the Bloody Newroz (Avebury, 1996). Also, most of the ceasefires between the PKK 'Kurdistan workers party' and the Turkish government have been in Newroz such as the first ceasefire in 1993 and the last one in 2013 (Ensaroğlu, 2013). In recent years, Kurdish people in each Kurdish city in Turkish Kurdistan set a different day to go out and celebrate. Even now there is no official holiday for Newroz in Turkey. Nonetheless, the Kurdish elected municipalities or the pro-Kurdish parties such as HDP and DBP take responsibility and organize the celebrations. They use Newroz to raise awareness about the Turkish state's fascist policies. Each year they name Newroz differently such as 'Newroz of freedom, Newroz of peace, Newroz of resistance, etc.' Nowadays, the biggest Newroz celebrations are in Diyarbakir 'Amed', which mainly happen on 21st of March. Yearly, millions of Kurds gather in the Newroz yard and renew their demand for freedom, peace, and independence (Phillips, 2017).

Kurds in Iran have been under Persian influence for a long time (Izady, 1992). However, they have kept their culture to a great extent. Interestingly, similar to the Persians, Kurds in Iran celebrate Newroz according to the Spring Equinox. They light the Newroz bonfire in the last 
evening of Rashame and start to celebrate and visit each other on the first date of Khakalewa. Nowadays, Kurdish Newroz in Iranian Kurdistan is under the influence of the association of

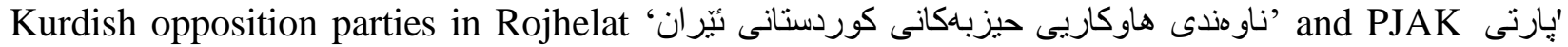
'زيانى ئاز ادى كوردستان'، They name Newroz according to the Kurdish political situation and ask the locals to celebrate in some places like Nê, Silvana, Nastan..etc. Similar to other parts of Kurdistan, this is a political show against the oppression of the Iranian regime.

For decades, the Kurds in Syria had been politically less active than those living in other parts of Kurdistan. However, they also faced obstacles when they tried to hold Newroz celebrations. Since the Alawites in Syria also celebrate Neworz, it made it easier for the Kurds to observe it (Izady, 1992). Syrian Kurds became a significant political group with the emergence of the Syrian civil war and managed to control their native region known as 'Rojava' in the North of Syria. Before the Syrian civil war in 2011, many of them were not given citizenship, and they were under oppression (McDowall, 2004). After they controlled Rojava, like the Kurds in the Kurdistan Region of Iraq, they legalized Newroz. Currently, Newroz is a national holiday for three days in Rojava. When Turkey and its mercenaries occupied the Kurdish populated city, Afrin, they first ruined the statue of Kawe in the Afrin city center as the symbol of the defeat of Kurdish forces and the erasure of their ethnic identity (Ashawi, 2018). This has a profound meaning and proves that Newroz and its legendary figure Kawe have not only been seen as national symbols by Kurds themselves but other the neighboring ethnic groups and nations also see them as symbols of the Kurdish national identity.

\section{Persian Nowruz Rituals}

Nowruz is one of the most important celebrations for Persians as well. This festival embodies a wealth of ancient rites and customs. It symbolizes the continuity of the ancient Persian culture, which has survived many adversities and uncertainties. Nowruz is the beginning of the Persian New Year as well. Heydari-Malayeri says Nowruz has been celebrated for over 3000 years on the first day of spring or Equinox which usually falls on 19th - 21st March, and it marks the first day of Farvardin of the Islamic solar calendar. However, he has no proof of what he says. According to a study by Heydari-Malayeri (2004), about $64 \%$ of all Nowruz events happen on March 20 for the Tehran longitude (see table 1).

Table 1

Persian Equinox Dates for Period A.D. 1583-2500

\begin{tabular}{ccc}
\hline March Date & Event frequency & Percentage $(\%)$ \\
\hline 18 & 0 & 0 \\
19 & 33 & 3.6 \\
20 & 584 & 63.6 \\
21 & 301 & 32.8 \\
22 & 0 & 0 \\
\hline
\end{tabular}

The Nowruz event consists of many rituals and those rituals have changed over time due to the social and cultural changes emerging from various parts of the region. Among the Persians, the first day of Nowruz is celebrated by visiting family and friends and exchanging gifts. Persians believe Nowruz is a reminder of values that bind all people together with the aim of mutual understanding, unity, and peace. In the Persian culture, Nowruz preparations start with a springcleaning or Khane-tekoni 'cleaning home'. The purpose is to clean the homes of clutter and dust 
that have settled there over the past year. Thus, the New Year will bring cleanness and freshness to families. Grass growing also takes place before Nowruz with the purpose of reproduction and renewal. Grass is one of the seven items of Haft-sin. Haft-sin table consists of seven symbolic objects beginning with the letter ' $S$ ' 'سـ' in the Persian alphabet'. Each piece has a specific meaning and symbolic significance listed in Table 2. As New Year comes closer, family members gather together around the Haft-sin table and wish for a healthy and happy year (Zamani-Farahani, 2013). The reason behind choosing seven items in Haft-sin might be related to the unique sense of number 7 in Persian mythology. According to Alavijeh (2013), seven levels exist to achieve divinity in Zoroastrianism, and Earth also consists of 7 parts based on the teachings of this religion. People sit around this 'Sofre' 'tablecloth' half an hour before the moment of the transition to the New Year.

\section{Table 2}

Haft-Sin Main and Symbolic Item Meaning

\begin{tabular}{ll}
\hline Main seven items & Symbolism \\
\hline 1. Sib 'apple' & Health, beauty \\
2. Sabzeh 'grass' & Exhilaration, rebirth, and renewal of nature \\
3. Senjed 'sweet, dry fruit of the lotus & $\begin{array}{l}\text { Love, affection } \\
\text { The colour of sunrise, the spice of life }\end{array}$ \\
tree.' & $\begin{array}{l}\text { Patience, age } \\
\text { 5. Somaq 'sumac.' }\end{array}$ \\
6erekh 'vinegar.' & For good health, medicine \\
6. Sir 'garlic.' & Sweetness of life, fertility \\
7. Samanu 'wheat pudding.' & Symbolism \\
\hline Additional symbolic items & Reflection of the past, brightness, honesty \\
1. Mirror & The earth in the space \\
2. Orange in a bowl of water & New life \\
3. Goldfish in a bowl of water & Fertility \\
4. Colourful eggs & Prosperity, wealth \\
5. Coins & Spring, life, beauty \\
6. Unique flowers called Sombol & Happiness, light, energy \\
7. 'hyacinths' & Bring health, for staying away from the evil \\
8. Esfand 'sacred herb.' & eye \\
\hline
\end{tabular}

The actual Nowruz ceremonies begin on the eve of the last Wednesday of the year referred to as Chaharshanbe-Suri. A fire ceremony is held in which people get together near the sunset and jump over fires while shouting: 'Sorkhi-e to az man' 'Give me your beautiful red colour,' 'Zardie man az to' 'take back my sickly pallor.' The purpose of this ceremony is to strengthen people's relations and friendships (Simaei, 2008). Chaharshanbe-Suri, which precedes Nowruz and involves many traditions that have originated in the Zoroastrian tradition about $1725 \mathrm{BC}$ (Richter, 2005).

Chaharshanbe-Suri consists of different activities in which making fires and jumping over them are the main part, followed by spooning 'Ghashogh-zani', Ash-e morad 'wish pottage,'Falgoosh and Shal-andazi'.

Finally, Nowruz ends with Sizdehbeder-13 days after Nowruz, which also is known as Nature day in Iran. People go to the countryside with their relatives and spend a day in nature, playing games, sightseeing, etc. Young girls tie the Nowruz grass while singing a traditional song, hoping to have a good marriage or a new child before the next Nowruz (Simaei, 2008, p. 1404). 
Attitudes toward Nowruz have been both positive and negative throughout history. Regarding the sociological perspective, factors such as human acting and social structure 'specifically dominant structures of government' are associated with conformity and nonconformity of Nowruz followers with the Nowruz rituals (Bigonah, 2016).

\section{Methodology}

In this study, the qualitative method and semi-structured interviews used to collect data from Kurdish and Persian students of Eastern Mediterranean University, North Cyprus. Participants were selected using a judgmental sampling technique. Semi-structured interview is a verbal interchange where the interviewer attempts to gather information from another person by preparing some questions that identify the theme. While the focus is on the theme, interviewer attempts to broaden the theme to discover more information related to the topic (Qu \& Dumay, 2011). The semi-structured interview is the most common method of qualitative research methods as it is flexible, accessible, and understandable (Kvale \& Brinkmann, 2009).

Face-to-face individual interviews used to gain an in-depth understanding of major similarities and differences between Kurdish and Persian Newroz/ Nowruz and also to explore whether living abroad caused any changes in the way students decelerate Nowruz/Newroz. To be sure about the discussions and the significant issues, an interview guide was designed. Therefore, the main topics to be discovered were (1) participants' prospects toward Newroz/Nowruz event (2) the meaning of Newroz/Nowruz from participants' point of view (3) the main activities that are taken during Newroz/Nowruz and (4) differences between Newroz/Nowruz celebrations at home and abroad.

Participants of this study were students from two different national backgrounds; 5 Kurds and 5 Persians. Respondents were 6 females and 4 males, and all of them were below 35 years. Table 3 represents the participants' profile. All interviews conducted somewhere inside the university campus. Interviews lasted about $30-45$ minutes. All parts were audio-recorded and transcribed in Persian and Kurdish. To avoid misunderstanding, back translation was done. The data gathered was interpreted and then analyzed. Data were analyzed based on the study of Berg et al. (2004) in three steps: (1) materials were carefully read to enhance the researchers' understanding and preparation for coding. (2) according to the study literature, categories and coding frames were designed (3) finally; the coding list was used to develop the concepts of the theoretical framework of the study. Each participant was given an ID number for reporting the findings of the study.

\section{Table 3}

\begin{tabular}{llllll}
\multicolumn{2}{l}{ Respondents 'Profiles } \\
\hline ID & Gender & Age & Position & $\begin{array}{l}\text { Been to North } \\
\text { Cyprus from }\end{array}$ & Community \\
\hline 1 & Male & Below 25 & M.S student & 2015 & Kurdish \\
2 & Female & $26-35$ & PHD student & 2014 & Kurdish \\
3 & Female & Below 25 & B.S student & 2014 & Kurdish \\
4 & Male & $26-35$ & PHD student & 2016 & Kurdish \\
5 & Male & $26-35$ & PHD student & 2015 & Kurdish \\
6 & Female & $26-35$ & PHD student & 2013 & Persian \\
7 & Female & Below 25 & M.S student & 2011 & Persian \\
8 & Female & $26-35$ & M.S student & 2015 & Persian \\
9 & Female & $26-35$ & PHD student & 2012 & Persian \\
10 & Male & $26-35$ & PHD student & 2012 & Persian \\
\hline
\end{tabular}




\section{Findings: Newroz Origin and Symbolic Meanings}

Participants were asked to explain their general view and the mythology of their ethnic groups. Findings indicate that there are some differences in the origin of Newroz/Nowruz celebration from these two groups' perspectives. For Kurds, Newroz is a symbolic event. Kurds link Newroz with the myth of Kawe the blacksmith and Zuhak, the tyrant. According to them, Newroz is a symbol of freedom and fighting against dictatorships, and Kawe success leads to the emergence of the Median Empire:

The history of Newroz began from the myth of Kawe and Zuhak. Thousands of years ago, there was a wicked dictator, 'Zuhak'. One day Kawe fought him and killed him with his hammer. Kurdish people then lit a bonfire on the top of a mountain to celebrate the end of a dictatorship. Then, people of the area called that day as Newroz. Then the Kurdish Median Empire was founded (ID 5, male, 26-35).

In contrast, Persians are not much clear about the exact origin of Nowruz however they believe that this festival derived from the history of ancient Iranians which goes back to a thousand years ago. They think that every year, Zoroastrian used to celebrate the beginning of spring. It was for the renewal of the nature and fertility of the earth. Thus, for Persian people, Nowruz is the moment that the earth turns to its period of restoration.

Nowruz used to be celebrated at the beginning of the spring for thousands of years in ancient Iran. It has derived from the Zoroastrian religion and culture. Iranian people used to celebrate this event from the time of the Achaemenian Empire until today (ID 6, female, 26-35).

By looking at the literature and the interviews together, we see that the Kurdish Newroz tradition has changed a lot because of the Kurdish political situation. Newroz has evolved from being a cultural event into a political event and has created a sense of collective identity for the Kurds to protect their national identity from being dissolved in the state identities. The new understanding of Newroz has started since the collapse of the Ottoman Empire. The Kurds, in particular from the city of Sulaymaniyah started to use Newroz as a day of their resistance against the formation of the Iraqi state by the British mandate. The famous Kurdish poem 'Newroz' by Piramerd, which later sang by Hasan Zirak has had an enormous impact on the young generations.

Different results also were found regarding the exact day and time of Newroz/Nowruz. Most of the Kurdish participants specified that the precise day of Newroz is on the 21 st of March every year and they start the celebration in the evening on 20th March. However, Iranian Kurds still celebrate Newroz according to the Spring Equinox. Kurdish months, which are designed according to the Vernal Equinox are: Khakalewa [xa:kele:we], Gullan [guła:n], Zardan [zerda:n], Pushpar [puJper], Galawezh [gela:we:3], Kharmanan [xerma:na:n], Baran [bera:n], Khazan [xeza:n], Saran [sa:ra:n], Bafran [befra:n], Rebandan [re:benda:n], Rashame [refeme:] (ID 4, male, 26-35).

On the other hand, Persian participants indicate that the exact day and time of Nowruz changes every year according to their solar calendar. They added that it might happen in 19, 20, or $21_{\text {st }}$ of March in different hours, minutes, and seconds of the day. The Persian months are: Farvardin [færvær'di:n], Ordibehesht [ordi:be'heft], Khordad [xor'dp:d], Tir [ti:r], Mordad 


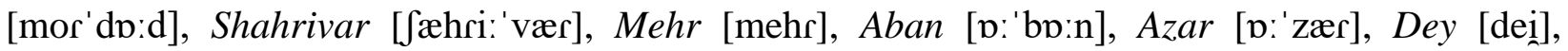
Bahman [bæh'mæn], Esfand [es' fænd] (ID 6, female, 26-35).

Findings also indicate that the period of Kurdish Newroz is three days, which is a holiday in Kurdistan Region of Iraq and The Autonomous Administration of North and East Syria 'Rojava' (ID 1, Male, below 25). Kurdish people of Iran also have the chance to celebrate the holiday during the official Persian holiday for Nowruz. However, the Iranian regime has restricted Kurdish Newroz celebrations and gatherings. Regarding Turkey, the state uses all kinds of techniques to prevent Kurdish people from celebrating Newroz. Fortunately, the Turkish government's propaganda has not been effective in recent years. In Iran, Persians celebrate for about a week, and after the thirteen days, they go out for a picnic, which is called Sizdehbeder. However, the way to celebrate has been changed a lot due to the influence of the Islamic regime in the country. The new system does not allow those activities that are against Islamic rules; for example, dancing in public.

It is also worth mentioning that there are some specific signs of Newroz for Kurdish people such as fire, two fingers up, Kurdistan flag colors 'yellow, green, and red', Newrozi gift, and Narges 'narcissus' that is a unique flower that grows in spring. Currently, Newroz itself converted into a political festival, and the political messages highlighted as Kurds always seek for independence. However, participants noted that there are some other symbolic meanings of Newroz, such as peace and resistance (ID2, female, 26-35). Another informant believed that Newroz could bring Kurds a political success (ID 1, male, below 25). In contrast, for Persian people, 'grass' was noted as the essential item of Nowruz, which is the symbol of rebirth and renewal. (ID 8, female, 26-35).

The findings of this study reveal that for Kurdish people, Newroz is mainly a political event, especially in recent years since it allows them to express their desire for independence and freedom. However, for Persians, it is a cultural event that takes place every spring to celebrate New Year without any political pressure.

\section{Findings: Nowruz Traditions and Activities}

Regarding the cultural activities that take place during Newroz/ Nowruz festivals, many similarities and differences were found between Kurdish and Persian culture. In Kurdish culture, there is something called Newrozî 'Newrozi gift - نهوروزي'. Children go out and knock the doors for Newrozi, which is called Helawe Melawe. Helawe Melawe is the name of the song that they sing on that day. People give them different kinds of gifts, namely a colourful egg. They prepare such eggs by boiling them with an onion, so the eggs get a colour. Nowadays, people use different colours to dye their eggs in Newroz. They also wear colorful Kurdish clothes that are mostly decorated in green, red and yellow which are the colours of the Kurdistan flag. They dance together and have fun because of the new year (ID 2, female, 26-35). The lovers give each other a unique gift that is mostly the Kurdish clove apple 'سيَّى ميخذك ريّز Kurdish gift that the lovers provide it to each other as a Newrozi(ID 4, male, 26-35).

In Persian culture, some activities take place before the day of Nowruz, such as Khanetakani 'cleaning house', grass growing, Chaharshanbe-Suri, and buying new clothes. There is no rule for starting Khane-tekani. It depends on people's situation, and buying new clothes usually needs to be done before the transition day (ID 8, female, 26-35). Persian participants did not mention wearing traditional clothes in Persian Nowruz, and they do not have Newrozi gift and clove apple, which are a part of the Kurdish Newroz tradition. Activities such as Khane-tekani and grass growing were not mentioned by Kurdish participants.

In both cultures, people light a bonfire before the day of Newroz. On the one hand, Persians

light the bonfire on Chaharshanbe-Suri 'last Wednesday of the year' and jump over it while 
wishing for health and happiness. For Persian people, fire is the symbol of cleanness, which is linked to the Zoroastrian religion.

We use to celebrate it on the last Wednesday of the year. Usually, near the sunset, we make some small fires in different spaces in our homes yard or on the street. Then we get all together with family members and friends while repeating 'Zardiye man az to, Sorkhi to az man', jumping over fire. I think this tradition rooted in the Zoroastrian religion because they believed that fire is the cleanest and purest thing in the world (ID 6, female, 26-35).

On the other hand, Kurdish people light the bonfire night before the day of Newroz and dance around the fire while wishing for freedom and peace. Similar to the Persians, they also believe that lighting the fire has a link to the Zoroastrianism.

There are big celebrations on the evening of 20th March, and we use to make a fire, and we all gather together around the fire, dance, and wish for freedom. The celebrations could be enormous, and sometimes millions of people gather in the cities like Erbil and Sulaymaniyah (ID 3 , female, below 25).

Although some Iranian Kurds believe Chaharshanbe-Suri is not a part of their culture, nowadays some young Kurds of Iran also celebrate it in the way Persians do (ID 1, male, below 25). It is proof of the influence of the dominant culture on the ethnic minority cultures.

Both Persian and Kurdish participants mentioned traditional foods, songs, and dances for the day of Newroz/ Nowruz. In fact, these activities are an inseparable part of Nowruz in every culture:

We use to cook traditional Persian meals for each specific day of Nowruz. For Chaharshanbe-Suri we use to cook Ash Reshte 'special Persian soup' and in the day of Nowruz, Sabzi polo mahi 'rice mixed with vegetables and fish'. We have also many different types of traditional sweets and cookies that we use to serve in Nowruz period (ID 9, female, 26-35).

Usually, one day before Newroz, we use to buy meat and nuts, and many other foods depending on the house situation and family prefers. Still, Dolma, barbeque, and Biryani are the preferred foods of Kurdish people on this day (ID 4, male, 26-35).

According to the participants, picnic is also an important part of Newroz/ Nowruz in both cultures. However, Persians use to go for a picnic on the 13 th day of Farvardin ' 13 day after the beginning of Nowruz', while Kurds use to spend almost all the three days of Newroz on a picnic. In Persian Culture Nowruz period ends with 13-be-dar, which also is known as nature day (ID 7, female, below 25). According to Persian participants, water is a symbol of brightness, and by throwing Nowruz grass into water, their wishes might come true. Moreover, findings indicate that Persians design and have a Haft-sin table for Nowruz, but the Kurdish people did not mention Haftsin. 


\section{Findings: Celebrating Newroz Abroad}

Almost all the participants of this study have stated that celebrating Newroz/Nowruz in their home country is different from what they experienced during Newroz celebrations in Cyprus. Both Kurdish and Persian students have said that they gather with their friends, family, and loved ones in their home countries. While this is not the case in North Cyprus. Some of the participants indicated that they are not able to easily celebrate this event as they have to do many tasks related to their study (ID 10, male, 26-35). Furthermore, Some of the Kurdish students were complaining that the university administration underestimates Kurdish Newroz, and they deliberately try to prevent them from celebrating it. The university administration congratulates Persians for Nowruz, while they ban Kurdish Newroz. They also blamed their instructors for approving the Persian students's requests to submit their assignments late during Newroz/Nowruz while they rejected similar requests made by the Kurdish students.

Every time on the $21_{\text {st }}$ of March we have a lot of quizzes, and we can't go back to our Kurdistan and if we are going to celebrate Newroz here, then we usually should attend the programs arranged by our society. There are some Turkish restrictions. We cannot celebrate Newroz here as we wish (ID 5, male, below 25).

The findings of the study also reveal that students of both communities are influenced by each other's culture in celebrating Newroz/ Nowruz. However, Kurdish students seem to be under greater Persian influence as they represent a smaller community than the Persian students there.

Table (4) shows a summary of the similarities and differences between Kurdish and Persian Newroz/ Nowruz.

\section{Table 4}

The Main Differences and Similarities Between Kurdish and Persian Newroz/Nowruz

\begin{tabular}{|c|c|}
\hline Kurdish Newroz & Persian Nowruz \\
\hline Political and Cultural festival & Cultural festival \\
\hline The main symbols are: & The main symbols are: \\
\hline $\begin{array}{l}\text { Fire, Green, red and yellow colours, Two fingers up } \\
\text { Newrozi gift (such as Vinsev and colourful egg). }\end{array}$ & Fire, Chaharshanbe-Suri, Haft-sin, Khane-tekani \\
\hline $\begin{array}{l}\text { Politically, it is the symbol of Kurdish resistance against } \\
\text { the four states, and Kurdish unification. }\end{array}$ & No political meaning \\
\hline The main activities are: & The main activities are: \\
\hline $\begin{array}{l}\text { Political gathering and celebration, Picnic and going } \\
\text { countryside, Lighting a bonfire, dancing and singing }\end{array}$ & $\begin{array}{l}\text { Gathering in small groups, Picnic and going countryside, } \\
\text { dancing and singing }\end{array}$ \\
\hline $\begin{array}{l}\text { Three days are holiday in Kurdistan Region of Iraq and } \\
\text { Rojava, no holiday in Turkey. }\end{array}$ & $\begin{array}{l}\text { Five days in governmental offices and thirteen days in } \\
\text { educational institutions are holiday in Iran. }\end{array}$ \\
\hline $\begin{array}{l}\text { According to Kurdish mythology, Newroz has started } \\
\text { since the emergence of the Median Empire and killing } \\
\text { Zuhak by Kawe, which leads to building the Empire. } \\
\text { Also, it is under Zoroastrianism influence. }\end{array}$ & $\begin{array}{l}\text { According to Persian mythology, Nowruz has started } \\
\text { when Jamshid the king won a fight against winter, and } \\
\text { blessing fire comes from Zoroastrianism. }\end{array}$ \\
\hline $\begin{array}{l}\text { Currently, Kurds celebrate it freely in Kurdistan Region } \\
\text { - Iraq and Rojava, while there are many obstacles in } \\
\text { front of them in Turkey and Iran. }\end{array}$ & $\begin{array}{l}\text { No obstacles in front of Nowruz, while the Islamic rules } \\
\text { have affected the way that people celebrate. }\end{array}$ \\
\hline $\begin{array}{l}\text { In overseas, it is restricted by the Turkish oriented } \\
\text { authorities, such as North Cyprus. }\end{array}$ & No restrictions are recorded abroad. \\
\hline Current Kurdish year is 2720 & Current Persian Year is 1399 \\
\hline
\end{tabular}




\section{Discussion and Conclusion}

The study aims to understand the similarities and differences of the views about the origin of Newroz/ Nowruz, its cultural value, related customs, rituals, and the way it is celebrated at home and abroad. The results of the interviews have revealed the similarities and differences between Kurdish and Persian Newroz/ Nowruz. Interestingly, there are many significant differences between the two nations in the way they celebrate the festival. Persians perform this and other cultural activities and rituals with governmental support while there is not a unified Kurdish political system to support and promote the celebration of the festival due to the political context of Greater Kurdistan. Kurdish Newroz is a national holiday in Kurdistan Region of Iraq and Rojava. Kurds in Turkish and Iranian Kurdistan celebrate it in the face of many political obstacles.

Newroz/ Nowruz dates back to ancient history. Kurds link it with the advent of the Median Empire and the rise of Kurdish legend Kawe, a blacksmith who stood against Zuhak while Persians relate it to the mythology of Jamshid. However, they both agree that Newroz/ Nowruz has some connections with the ancient religion of Zoroastrianism that considers 'fire' as a symbol of holiness.

The first day of Kurdish Newroz is on the 21 st of March which can be the day of the spring equinox while the date would change according to the Persians and it could be on 19th, 20th, or $21_{\text {st. }}$ The length of the festival is three days for Kurds and 13 days for Persians. In Turkey, there is no official Newroz holiday for Kurds. In Iran, fireworks and its related rituals are celebrated a couple of days before the great eve. Persians start their celebration on the evening of the last Wednesday, and it is called 'Chaharshanbe-Suri'. However, Kurds light the bonfire on the evening of the 20th of March and hold public celebrations.

There are some other symbols besides the fire, which are mentioned by the Kurdish interviewees, such as two fingers up, the three colours, Newrozi, etc. As mentioned before, for Kurdish people, Nowruz is the symbol of Kurdish unification and resistance. For Persians, a very custom of Nowruz is 'Haft-sin' which was mentioned by all the Persians during the interviews. The items of 'Haft-sin' seem to be similar among Persian families, but there is not 'Haft-sin' in Kurdish culture.

Another important item of Newroz/ Nowruz festival is food. Both Kurds and Persians serve nuts, sweets, coffee, and tea during the holiday. Special homemade meals are prepared for the New Year dinner. Kurds make Kurdish cuisine like 'Dolma' and Persians cook 'Sabzi polo mahi'. Food, music, and dance are the integral elements of Newroz for Kurdish people. In Kurdistan, men and women put on their traditional clothes and dance in a circle around the bonfire. Among Persians, however, dancing in public is neither popular nor legal in Nowruz due to current Islamic rules that regulate all aspects of public life in Iran. All Kurdish and Persian participants stated that they go to a picnic, do barbeque and enjoy nature with family members. Persians have 'Sizdehbeder' to go out while Kurds go out in the three days.

Things related to national customs are quite different for overseas students. All the participants mentioned that they could not celebrate Newroz/ Nowruz in the way they do in their home countries. Persians have also gathered together for 'Chaharshanbe-Suri' and 'Sizdehbeder'. They mentioned that school offers a limited opportunity to celebrate Newroz in the way they like. Some of Persians said that they prepare 'Haft-sin' and eat 'Sabzi polo mahi' as the first dinner of Nowruz. An interesting point that has been stated by Kurdish students is that the university and Turkish authorities in North Cyprus request Kurds not to celebrate their festival in the Kurdish way. 
In summary, the findings of this study align with the literature about Newroz. Rituals are similar to the ones described in the literature (Heydari \& Malayeri, 2004; Simaei, 2008). 'Haft-sin' and its elements are also identical to the previous studies (Zamani-Farahani, 2013). Notably, even the political perspective of Kurds related to Newroz is consistent with previous studies (Jamison, 2016; Kayak, 2015; Yanik, 2006), while there are some new findings regarding the Kurdish culture because it is an area of cultural studies that have not been studied thoroughly. This study is one of the first studies that investigate the concept of Newroz/Nowruz festival from two different cultural perspectives 'in this case of Kurds and Persians'. Given the fact that many other countries such as Azerbaijan, Afghanistan, Tajikistan, etc. also celebrate the festival under similar names such as Newroz, Nawrouz, Novruz, Nowrouz, Nowrouz, Nawrouz, Nauryz, Nooruz, Nowruz, Navruz, Nevruz, Nowruz, and Navruz. Future studies can use longitudinal research like direct observation to find out more specific and valuable inferences about this rich festival. As the target group of this study was limited to 10 students abroad, conducting a new study with a larger member of interviewees might lead to gain more precise information in this field. Moreover, future research can focus on Newroz celebration among immigrants and their challenges in performing their traditions in their host communities.

\section{References}

Alavijeh, A. Z. (2013) A Comparison between the significance of Number 7 in Persian Context and Number 9 in Chinese Context, ISS \& MLB, 1155-1160

Anwar, K. A. (2016). Kurds and the history of the Newroz feast [كورد و ميّزووى جهزنى نهوروزّ]. Idea foundation.

Ashawi, K. (2018). Turkey-backed forces pull down Kurdish statue in Afrin town center: Statement. Reuters. http://tiny.cc/ukwpnz

Avebury, L. (1996). Turkey's Kurdish policy in the Nineties. The International Journal of Kurdish Studies, 9(1), 1-34.

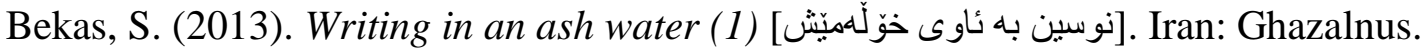

Belyaev, O. (2010). Evolution of case in Ossetic. Iran and the Caucasus, 14, 287-322.

Berg, B. L., Lune, H., \& Lune, H. (2004). Qualitative research methods for the social sciences (Vol. 5). Pearson.

Bigonah, H. (2016). Nowruz in tradition transition. IIOABJ, 7(3), 491-495.

Crompton, J., \& McKay, S. (1997). Motives of visitors attending festival events. Annals of Tourism Research, 24(2), 425-439.

Cudny, W. K., Korec, P., \& Rouba, R. (2012). Residents' perception of festivals: A case study of Lodz. Sociologia, 44(6), 704-728.

Ensaroğlu, Y. (2013). Turkey's Kurdish question. Insight Turkey, 15(2), 7-17.

Firdawsi, A. (2006). Shahnameh: the Persian book of kings. Viking.

Getz, D. (1993). Corporate culture in not-for-profit festival organizations. Festival Management and Event Tourism, 1(1), 11-17.

Hakim, B. (2016). Newroz is celebrated in the Piramerd house [له مالّى بِير مميّرد يادى نـوروز دمكريتنهوه]. Rudaw. https://www.rudaw.net/sorani/kurdistan/200320166

Heydari-Malayeri, M. (2004). A concise review of the Iranian calendar. arXiv preprint astroph/0409620. Cornell University.

Hirschler, K. (2001). Defining the nation: Kurdish historiography in Turkey in the 1990s. Middle Eastern Studies, 37(3), 45-166.

Izady, M. (1992). The Kurds:A concise handbook. Taylor and Francis. 
Jamison, K. (2016). Hefty dictionaries in incomprehensible tongues: Commensurating code and language community in Turkey. Anthropological Quarterly, 89(1), 31-62.

Janiskee, R. (1980). South Carolina's harvest festivals: Rural delights for day tripping urbanites. Journal of Cultural Geography, 1(1), 96-104. https://doi.org/10.1080/08873638009478655

Kaya, Y. (2015). The Opinions of Primary School, Turkish Language and Social Science Teachers regarding Education in the Mother Tongue (Kurdish). Journal of Ethnic and Cultural Studies, 2(2), 33-46.

Kolcak, H. (2015). A New Constitution for a Stable Nation: A Constitutional Study on the LongRunning Kurdish Question in Turkey. Journal of Ethnic and Cultural Studies, 2(1), 29-48.

KRG. (2020). National holidays and key dates in the Kurdistan region's history. Department of Foreign Relations. http://dfr.gov.krd/p/p.aspx?p=290\&l=12\&r=367

Kvale, S., \& Brinkmann, S. (2009). Interviews: Learning the Craft of Qualitative Research Interviewing. Sage.

Luna, A. M. (2015). A festival's impact: The case of the Bañamos Festival. International Refereed Research Journal, 6(1), 48-58.

McDowall, D. (2004). A modern history of the Kurds. London: I.B.Tauris \& Co Ltd.

Okech, R. N. (2011). Promoting sustainable festival events tourism: A case study of Lamu Kenya. Worldwide Hospitality \& Tourism Themes, 3(3), 193-202.

Özoglu, H. (2004). Kurdish notables and the Ottoman state. New York, NY:State University of New York Press.

Phillips, D. L. (2017). An uncertain ally: Turkey under Erdogan's dictatorship. London: Routledge. Qeredaxî, N. (2017, March 20). Newroz le efsane û symbulêk wawetir. Ashte. http://ashte.org/index/?p=5298

Qu, S. Q., \& Dumay, J. (2011). The qualitative research interview. Qualitative Research in Accounting \& Management, 8(3), 238-264.

Richter, J. (2005). Iran the culture. Iran: Crabtree Publishing Company.

Simaei, J. (2008). Nowruz ceremonies, cover 2 [جشن هاى نوروزى]. Iran: Simro publications.

Thrane, C. (2002). Music quality, satisfaction, and behavioral intentions within a jazz festival context. Event Management, 7(3), 143-150.

UNESCO. (2009). Nomination form. Retrieved July 10, 2019 from http:/fwww.unesco.org/culture/ich/doc/src/00282-Nomination_form.doc

UNESCO. (2010). The UN General Assembly recognizes 21 of March as the International Day of Nowruz at its sixty-fourth session. http://en.unesco.kz/the-un-general-assembly-recognizes21-of-march-as-the-international-day-of-nowruz-at-its

Woofter, S. (2019). Book Review: Building Equity: Policies and Practices to Empower All Learners. American Journal of Qualitative Research, 3(1), 136139. https://doi.org/10.29333/ajqr/5815

Yanik, L. K. (2006). 'Nevruz' or 'Newroz'? Deconstructing the 'invention' of a contested tradition in contemporary Turkey. Middle Eastern Studies, 42(2), 285-302.

Zamani-Farahani, H. (2013). Cultural heritage events and tourism: A case of NowRuz. Tourism Recreation Research, 38(2), 249-254. 